DOI: 10.15393/j2.art.2015.2981

Article

\title{
Capacity of the Dispute Settlement Body of the World Trade Organization for Resolution of Disputes Related to Trade in Forest Products
}

\section{Julia Maximova 1,*, Jouni Pykäläinen 2, and Timo Karjalainen 3,4}

1 Indufor Oy, Töölönkatu 11 A FI-00100 Helsinki Finland; E-Mail: julia.maximova@indufor.fi (M.S.)

2 University of Eastern Finland, Faculty of Science and Forestry, P.O. Box 111 Yliopistokatu 7, FI-80101 Joensuu Finland; E-Mail: jouni.pykalainen@uef.fi (Prof.Dr.)

3 Natural Resources Institute Finland (Luke), Yliopistokatu 6, P.O. Box 68, FI-80101 Joensuu Finland; E-Mail: timo.j.karjalainen@luke.fi (Res.Prof.Dr.)

4 University of Eastern Finland, Faculty of Science and Forestry, P.O. Box 111 Yliopistokatu 7 , FI-80101 Joensuu Finland; E-Mail: timo.karjalainen@uef.fi (Prof.Dr.)

* Author to whom correspondence should be addressed; julia.maximova@ indufor.fi (M.S.); Tel.: +358-503-833-732.

Received: 8 April 2015 / Accepted: 27 Jun 2015/ Published: 10 July 2015

\begin{abstract}
The World Trade Organization (WTO) regulates the world trade through establishing tariffs and elimination of non-tariff barriers and trade of its member countries covers $95 \%$ of the global trade. It sets up a common frame for commerce in goods, services and intellectual property extending its influence also to the forest sector through a number of mechanisms, one of which being the Dispute Settlement Body of the WTO. The aim of this paper is to shed light on possibilities of the Dispute Settlement Body to settle conflicts in trade of wood-based products and underline its importance as a negotiation platform for regulating international disputes. Analysis of the disputes in trade of forest products submitted for consideration of the Dispute Settlement Body reveals that such conflicts mostly relate to anti-dumping measures, safeguard actions and standards for exported wood and are often resolved by means of consultations between parties. However, failing to settle at this stage some cases have proceeded with a panel formation and been resolved by an ultimate panel ruling. Moreover, some of the cases have been solved by negotiation process instead of a panel process.
\end{abstract}

Keywords: World Trade Organization; Dispute Settlement Body; trade in forest products; resolution of disputes 


\section{Introduction}

The idea of creating an organization which would regulate international trade in goods can be traced back to late 1940s. In 194723 countries signed a General Agreement on Tariffs and Trade (GATT) with an idea of tackling the economical consequences of the World War II and avoiding the possibility of repeating the Great Depression of 1930s with its remarkably high tariffs and the policy of protectionism [1]. Initially the participants - mostly export-oriented developed countries - were mainly seeking for improving accessibility of their products in international markets and the GATT agreement intended to serve as a binding obligation of reducing tariffs among them [1]. However, back in the days the International Trade Organization was not meant to appear on the international stage due to a denial of ratification from the Congress of the USA [2]. Gradually since 1947 more countries decided to join the GATT Agreement and 8 rounds of negotiations were held with the last one (the Uruguay Round in Marrakesh in 1994) eventually giving birth to the World Trade Organization [1]. The name of the organization was proposed by Canada and supported by the United States on the contrary to the "Multinational Trade Organization" favored by the EU [3]. One of the reasons for the WTO creation was that the GATT though serving as a de facto organization was still an agreement lacking a legal framework of an institution along with increasing understanding of the necessity of expansion of trade of goods to trade in services and intellectual property [2].

As for 2014 the Organization has 160 members or $80 \%$ of all countries ${ }^{1}$. It is being financed by its members and the amount of a contribution depends on a country's share in trade with other WTO members calculated as an average of 3 most recent years (and if this share is less than $0,12 \%$, then a minimum contribution is applied) [4]. Every member gets one vote in decision-making regardless of its size or role in international trade and all decisions are being made by consensus [2]. The Organization itself is comprised of a Secretariat which is relatively small (640 as for 2011 [2] but the WTO believes that the organization has to be run by members rather by the Secretariat. It is generally assisted in its daily work by member states' delegations with an average of 5 professionals in each one forming various WTO committees and councils. The WTO has 19 Committees (plus 1 subcommittee), 7 working groups, 3 councils for trade in goods, services and intellectual property and the General Council (functioning as well as a dispute settlement body and a trade policy review body) meeting every month; nevertheless the highest decision-making right is granted to Ministerial

1 The list of observers and members with dates of the WTO entry is available at 
Conferences held every 2 years [5]. The specific functions of the WTO consist of organizing ministerial conferences, settling disputes, granting membership, conducting reviews of trade policies and implementation of WTO rules and decisions, as well as assisting negotiations [5].

The WTO regulates trade issues in a wide range of sectors and the forest sector is not an exception, though the Organization does not have a specific forest policy nor forestry experts in its staff. This influence is gained through the WTO capability of affecting tariffs for import of wood products, fighting trade distortive non-tariffs barriers, generating recommendations by its Committee on Trade and Environment, a number of agreements relating the WTO to the forest sector, as well as its policy affecting forest certification and eco-labeling. In addition to that, the WTO's Dispute Settlement Body has been given special authority for resolution of trade disputes and throughout its existence the DSB has dealt with a number of conflicts also in regards to trade in forest products.

The Dispute Settlement Body - a sui generis court of the World Trade Organization - is glue which holds tight all the agreements of the WTO and ensures that each member follows a set of rules necessary for effective functioning of the international trading system. Any member creating distortions for smooth trade and violating WTO rules can be brought up to the DSB and since the beginning of 1995, when the WTO DSB evolved officially from the GATT juridical system, several hundreds of cases have been submitted for its examination. The WTO underlines its priority for settling trade disputes by means of negotiations rather than panel procedures, therefore by 2008 only a third of all the filed cases had not been solved by consultations but by the ruling of panels [2].

To put it briefly, the process starts with a country issuing a complaint and asking a defendant for consultations which are lasting for a period of up to 60 days and if no mutual agreement is reached at this stage or if consolations are not wanted to last any longer, a complainant seeks an establishment of a panel which usually takes up to 45 days [2]. A panel comprises 3 or 5 independent experts from different countries chosen during consultations to look at the case and during next six months their task is to examine a case (as well as conduct two hearings), as well as to compile a report for DSB members [2]. As long as the report is not turned down by a consensus within 60 days it transforms into a final decision of the Dispute Settlement Body [2]. Thus, all in all these stages of settling a dispute may take up to a year, but if an appeal is made the procedure can prolong for 3 additional months. All the stages of the procedure can be summarized in a following figure (Figure 1): 


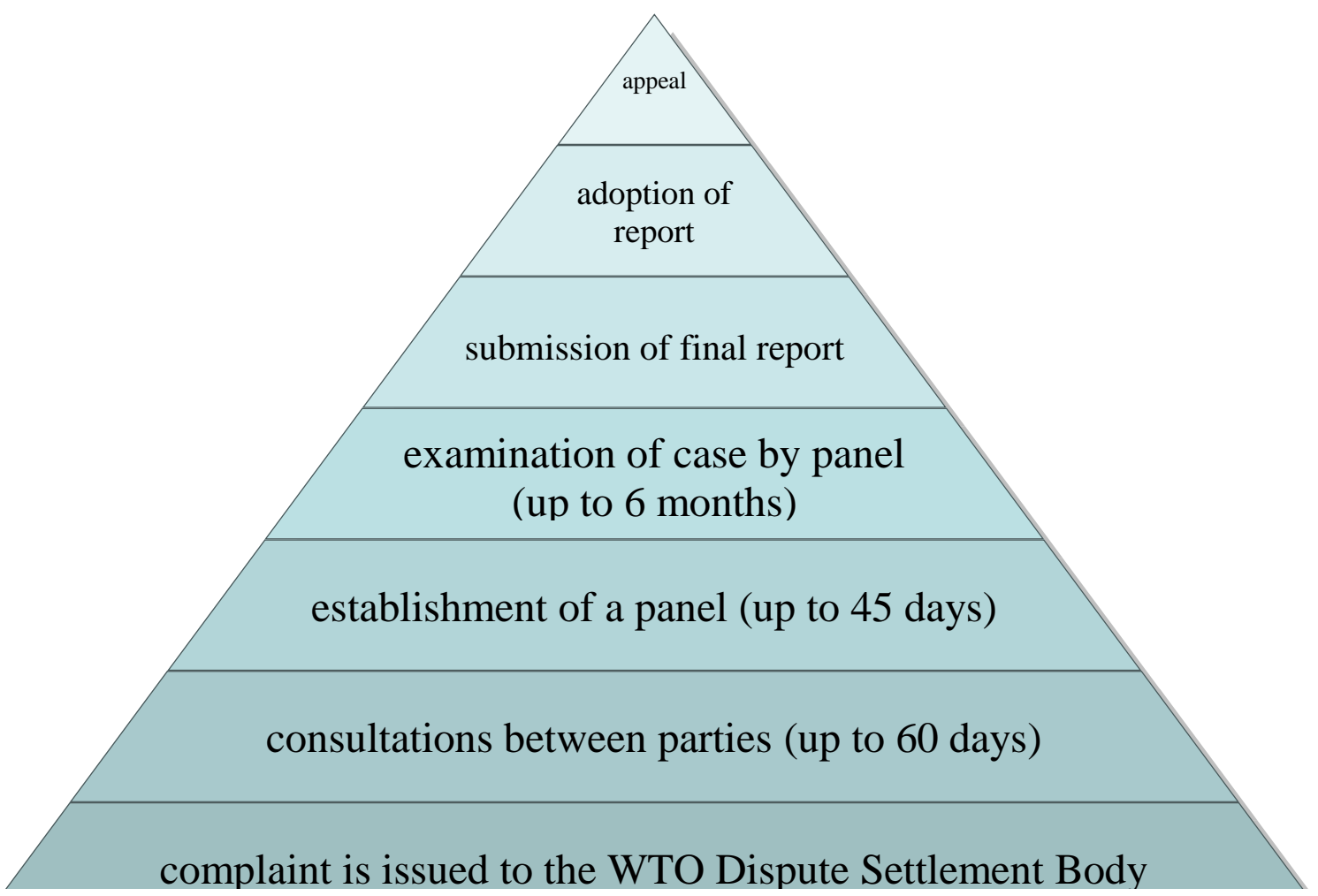

Figure 1. Process of dispute resolution by the DSB

In this study we analyze possibilities of the Dispute Settlement Body of the World Trade Organization to settle conflicts in trade of wood-based products based on few examples, showing the role of WTO as a negotiation platform for regulating international disputes.

\section{Materials and Methods}

All cases which have ever been submitted to the Dispute Settlement Body are recorded into the WTO database and as of January 2015 the DSB database has a record of 488 cases. The database in question allows extracting relevant cases according to several predefined parameters, such as register number, 
date, respondent/complainant/third party country, agreement in question or a subject ${ }^{2}$. The latter category has been of an interest for the current study and as the result of the search a total of 12 dispute cases related to trade in forest products have been chosen from the database and described on the basis of information available within it and various news articles. The cases have been analyzed and compiled into a single table (Table 1) representing the main outcomes and the stage at which a case has been resolved - within negotiations or after a panel ruling and presented in a nutshell above.

\section{Results}

China - Anti-Dumping Measures on Imports of Cellulose Pulp from Canada (DS 483). This latest dispute dated on October 15, 2014 has been initiated by Canada on grounds of unjustified antidumping measures restricting imports of Canadian pulp into China (WTO/DS483 2014). Earlier that year (in April 2014) China's Ministry of Commerce ruled on introduction of duties to be levied from Canadian, Brazilian and US cellulose pulp for a period of five years [6]. At the moment of writing the article both parties have been in the process of consultations.

European Communities - Measures Affecting Imports of Wood of Conifers from Canada (DS137). This case dating back to 1998 was based on Canadian allegations that custom measures introduced by the EU were negatively affecting Canada's export of coniferous wood to member states of the European Union (WTO/DS137 1998). The background for this issue was a 1993 requirement to pretreat all the wood imported to the EU (by means of kiln drying at 56 degrees during 30 minutes) causing Canada USD 400 million of losses annually [7]. The case did not proceed with a panel formation, what indicates that the parties had managed to settle this dispute within a negotiation process.

\section{United States - Preliminary Anti-Dumping and Countervailing Duty Determinations on Coated Free} Sheet Paper from China (DS368). Within this case on September 14, 2007 China issued a complaint against the USA over possibly introduced anti-dumping and countervailing duties by the latter (WTO/DS368 2007). This was preceded by accusations of the US Department of Commerce [8] that Chinese producers were dumping coated paper on the US market (selling it 21.12 to $99.65 \%$ less than market price and being subsidized by 7.40 to $44.25 \%$ ) and introduction of protectionist anti-

2 For the history of disputed cases settled by the WTO visit the DSB database available at 
dumping and countervailing duties. However, on December 21, 2007 the International Trade Commission of the United States announced that the duties for Chinese coated paper would not be imposed, as there were not enough grounds to prove that import of Chinese paper was impinging on domestic production of coated paper in the USA [9] and the case again didn't develop into a panel.

Ecuador - Definitive Safeguard Measure on Imports of Medium Density Fiberboard (DS303). In the framework of this case in 2003 Chile turned to the WTO settlement to address an issue of safeguards used by Ecuador when importing medium-density fiberboard (WTO/DS303 2003). Previous introduction of an extra 15\% custom duty on MDF as a safeguard measure to a "serious injury" of Ecuador's domestic MDF manufacturing followed by an establishment of an import quota amounting to 5401 million tons in July 2003 for a period of 2 years made Chile face significant economic losses and ask for consultations within the DSB [10]. After all, the case didn't proceed further into a panel formation and parties had managed to reach a consensus.

Korea - Anti-Dumping Duties on Imports of Certain Paper from Indonesia (DS312). This dispute began in June 2004 when Indonesia filed a complaint to the WTO as a reaction to Korean imposition of anti-dumping duties on imported business information paper and uncoated wood-free printing paper (WTO/DS312 2004). After unsuccessful bilateral consultations a case panel was established in August of 2004 and the panel reported that Korea had violated the Anti-Dumping Agreement, therefore demanding to correct its duties in accordance with its obligations to the WTO (WTO/DS312 2004). Nevertheless, as for 2010 Korea had not made any adjustment to its duties [11]. Whether the situation has faced any recent changes remains unknown due to the lack of information on this dispute.

If most of previously discussed disputes did not make it to a panel and sputtered out within a short period of time, a softwood lumber dispute between the US and Canada has incorporated 7 separate cases submitted for consideration of the WTO DSB and belongs to the largest (from the amount of capital involved in this bilateral trade) and the longest (more than 25 year history) trade disputes. The essence of the dispute lays in principal differences in stumpage price determination in Canada and the United States: whereas in the US with most forests belonging to private owners harvesting licenses are distributed through auctions, in Canada forests are public property and provinces are in charge of stumpage price determination, therefore prices might vary from one province to another [12]. As the 
result, a stumpage price in the USA is often much higher, than it is set in Canada, thus creating grounds for accusations in unfair subsidies for Canadian lumber [12].

Though being a stumbling block for Canada and the USA since early 1980s, the softwood lumber trade issue was first time brought to the WTO DSB in May 2000 [13]. In the frames of the first lumber dispute (case DS194) Canada challenged US determination of export restraints on lumber logs as a subsidy and back then the WTO ruled in its favor stating that export restraints should not be considered as a financial contribution of any kind [14]. It was followed by case DS221 initiated in January 2001, which again questioned the way the United States interpreted the WTO agreement (namely Section 129 c 1 of the Uruguay Round of Agreements) rather than actual trade sanctions in regard to lumber exports: however, this time Canada was unsuccessful in its attempt [14]. Next case in a caravan of lumber disputes was case DS236 from August 2001, where Canada filed a complaint against the US preliminary countervailing duties for Canadian softwood lumber followed by case $D S 257$, where contradictory countervailing duties in question were already final at the time when the complaint was again issued to the DSB (WTO/DS236 2001, WTO/DS257 2002).

In both disputes the panel ruled that the way the duties were determined by the United States contradicted the WTO Agreement on Subsidies and Countervailing Measures (SCM), however panel reports affirmed that Canadian provincial stumpage programs were countervailing subsidies to its producers of lumber [14]. Moreover, Canada also questioned fairness of preliminary anti-dumping measures (case DS247) applied by the US, but didn't proceed with a panel establishment within this case (WTO/DS247 2002). The so-called "lumber war" developed further with case DS264 in September 2002, which was based on an allegation of the US authorities that Canada was dumping its softwood lumber prices on the US market (WTO/DS264 2002). A panel report concluded that the US had fair reasons for questioning prices of exported Canadian lumber but the way the US Department of Commerce calculated its final anti-dumping measures on the basis of "zeroing methodology" was incorrect and needed revision [14]. In May 2002 the US International Trade Commission adopted new anti-dumping duties on Canadian lumber giving Canada again grounds for seeking for the WTO protection under case DS277 (WTO/DS277 2002). An expert panel of this case decided that a "threat of injury" was wrongly interpreted by the ITC and ruled in favor of Canada [13].

It is claimed that the WTO Dispute Settlement Body has not been a sufficient neither effective platform for settling this softwood lumber dispute between Canada and the USA, as due to a number of cases and appeals it has turned out to be long-lasting and rather costly in addition to revealing some 
inconsistencies between the WTO and the North American Free Trade Agreement (NAFTA) panel decisions (namely in regards to the "threat of injury" interpretation of the International Trade Commission of the US) [12]. An end of the dispute was laid in 2006 by reaching a consensus and adopting a Softwood Lumber Agreement, under which the USA was obliged to return 4 billion USD to Canada and not charge any duties on Canadian softwood lumber import during next 7-9 years, whereas Canada had to decrease by a third its import of lumber to the USA market [12]. Moreover, in case of future disputes they have agreed to turn to the LCIA (London Court of International Arbitration) instead of the WTO DSB [12].

\section{Discussion and Conclusions}

Dispute cases described in (Table 1) show that the majority of trade conflicts brought for consideration to the WTO Dispute Settlement Body had to do mainly with anti-dumping measures (like Canada vs. China, US vs. China, Korea vs. Indonesia), safeguard actions (like Ecuador vs. Chile) and standards for exported wood (like EU vs. Canada) and these issues appear to be the ones the WTO has most authority to solve. Therefore, such cases like any company dumping its prices of wood products on a foreign market, or a local forest industry facing any injury from increased foreign competition or unfair subsidizing of export of wood products may be and should be brought to the WTO DSB for seeking legal remedies in wood-related disputes. The importance of the Dispute Settlement Body of World Trade Organization as a negotiation platform for resolving international disputes related to trade in forest products should not be diminished either, as it still serves as an effective stage for reaching mutually favorable consensus instead of continuous and exhausting legal battles.

Settlement of trade conflicts concerning wood products by the means of the DSB may seem to be at a marginal level - 12 out of 488 , but on the average trade in forest products form just several percent of trade in products and even less if we add services and intellectual property. If judging upon presented cases one might form a perception that the DSB procedures are lengthy and it has been so, but recently the WTO has implemented measures for setting a specific time frame within which a case shall be ruled upon by a panel or appealed. Nevertheless, enhancing resolution of trade conflicts arising in the forest sector by the DSB would demand measures for increasing awareness of membercountries in a possibility of resorting to the DSB consideration of relevant trade issues, especially among developing and least-developed countries. 
Table 1. Disputes in trade of forest products brought to the WTO Dispute Settlement Body

\begin{tabular}{|c|c|c|c|c|c|c|}
\hline $\begin{array}{l}\text { DS } \\
\text { No. }\end{array}$ & Title & $\begin{array}{l}\text { Compl } \\
\text { ainant }\end{array}$ & $\begin{array}{l}\text { Respo } \\
\text { ndent }\end{array}$ & $\begin{array}{l}\text { Complaint } \\
\text { issued }\end{array}$ & Panel & Decision \\
\hline $\begin{array}{l}\text { DS } \\
483\end{array}$ & $\begin{array}{l}\text { Anti-dumping measures on } \\
\text { imports of cellulose pulp } \\
\text { from Canada }\end{array}$ & Canada & China & $\begin{array}{l}\text { October } \\
15,2014\end{array}$ & $\mathrm{X}$ & In consultations \\
\hline $\begin{array}{l}\text { DS } \\
368\end{array}$ & $\begin{array}{c}\text { Preliminary Anti-Dumping } \\
\text { and Countervailing Duty } \\
\text { Determinations on Coated } \\
\text { Free Sheet Paper from } \\
\text { China }\end{array}$ & China & US & $\begin{array}{l}\text { September } \\
14,2007\end{array}$ & - & $\begin{array}{l}\text { Resolved by consultations; } \\
\text { ITC of US pulled off the } \\
\text { proposal for duty levy. }\end{array}$ \\
\hline $\begin{array}{l}\mathrm{DS} \\
312\end{array}$ & $\begin{array}{l}\text { Anti-Dumping Duties on } \\
\text { Imports of Certain Paper } \\
\text { from Indonesia }\end{array}$ & $\begin{array}{l}\text { Indone } \\
\text { sia }\end{array}$ & Korea & $\begin{array}{l}\text { June } 4, \\
2004\end{array}$ & + & $\begin{array}{l}\text { The panel ruled in favor of } \\
\text { Indonesia and demanded } \\
\text { Korea to adjust its duties. }\end{array}$ \\
\hline $\begin{array}{l}\text { DS } \\
303\end{array}$ & $\begin{array}{c}\text { Definitive Safeguard } \\
\text { Measure on Imports of } \\
\text { Medium Density Fiberboard }\end{array}$ & Chile & $\begin{array}{l}\text { Ecuad } \\
\text { or }\end{array}$ & $\begin{array}{c}\text { November } \\
24,2003\end{array}$ & - & Resolved by consultations. \\
\hline $\begin{array}{l}\text { DS } \\
137\end{array}$ & $\begin{array}{c}\text { Measures Affecting Imports } \\
\text { of Wood of Conifers from } \\
\text { Canada }\end{array}$ & Canada & EU & $\begin{array}{c}\text { June, } 17 \\
1998\end{array}$ & - & Resolved by consultations. \\
\hline \multicolumn{7}{|c|}{ Series of softwood lumber disputes between Canada and US } \\
\hline $\begin{array}{l}\text { DS } \\
277\end{array}$ & $\begin{array}{l}\text { Investigation of the } \\
\text { International Trade } \\
\text { Commission in Softwood } \\
\text { Lumber from Canada }\end{array}$ & Canada & US & $\begin{array}{l}\text { December, } \\
202002\end{array}$ & + & $\begin{array}{l}\text { The panel ruled in favor of } \\
\text { Canada and admitted that } \\
\text { "threat of injury" } \\
\text { interpretation of US ITC was } \\
\text { misleading. }\end{array}$ \\
\hline $\begin{array}{l}\text { DS } \\
264\end{array}$ & $\begin{array}{c}\text { Final Dumping } \\
\text { Determination on Softwood } \\
\text { Lumber from Canada }\end{array}$ & Canada & US & $\begin{array}{l}\text { September, } \\
132002\end{array}$ & + & $\begin{array}{l}\text { The panel found out } \\
\text { drawbacks in the methodology } \\
\text { of US. determination of anti- } \\
\text { dumping and demanded } \\
\text { revision. }\end{array}$ \\
\hline $\begin{array}{l}\text { DS } \\
257\end{array}$ & $\begin{array}{l}\text { Final Countervailing Duty } \\
\text { Determination with respect } \\
\text { to certain Softwood Lumber } \\
\text { from Canada }\end{array}$ & Canada & US & $\begin{array}{c}\text { May, } 3 \\
2002\end{array}$ & + & $\begin{array}{l}\text { The panel concluded that final } \\
\text { countervailing duties violated } \\
\text { SCM and GATT Agreements. }\end{array}$ \\
\hline $\begin{array}{l}\text { DS } \\
247\end{array}$ & $\begin{array}{l}\text { Provisional Anti-Dumping } \\
\text { Measure on Imports of } \\
\text { Certain Softwood Lumber } \\
\text { from Canada }\end{array}$ & Canada & US & $\begin{array}{l}\text { March, } 6 \\
2002\end{array}$ & - & $\begin{array}{l}\text { The case didn't proceed with a } \\
\text { panel formation. }\end{array}$ \\
\hline $\begin{array}{l}\text { DS } \\
236\end{array}$ & $\begin{array}{c}\text { Preliminary Determinations } \\
\text { with Respect to Certain } \\
\text { Softwood Lumber from } \\
\text { Canada }\end{array}$ & Canada & US & $\begin{array}{l}\text { August, } 21 \\
2001\end{array}$ & + & $\begin{array}{l}\text { The panel rejected Canada's } \\
\text { complaints. }\end{array}$ \\
\hline $\begin{array}{l}\text { DS } \\
221\end{array}$ & $\begin{array}{c}\text { Section } 129(c)(1) \text { of the } \\
\text { Uruguay Round Agreements } \\
\text { Act }\end{array}$ & Canada & US & $\begin{array}{c}\text { January, } \\
172001\end{array}$ & + & $\begin{array}{l}\text { Canada failed in proving } \\
\text { inconsistency of the US law } \\
\text { with WTO trade rules. }\end{array}$ \\
\hline $\begin{array}{l}\text { DS } \\
194 \\
\end{array}$ & $\begin{array}{c}\text { Measures Treating Export } \\
\text { Restraints as Subsidies }\end{array}$ & Canada & US & $\begin{array}{c}\text { May, } 19 \\
2000\end{array}$ & + & $\begin{array}{l}\text { DSB decided the case in favor } \\
\text { of Canada. }\end{array}$ \\
\hline
\end{tabular}




\section{References}

1. Bown, C.P. 2009. Self-enforcing trade: Developing countries and WTO dispute settlement. Brooking institution press, Washington, USA, $157 \mathrm{pp}$. Available online: http://books.google.fi/books?id=j2dS8whqMSwC\&printsec $=$ frontcover\#v=onepage \&q\&f=false (accessed on 25 January 2015).

2. WTO. 2011. Understanding the WTO. WTO, Geneve, Switzerland, 113 p. Available online: http://www.wto.org/english/thewto_e/whatis_e/tif_e/understanding_e.pdf (accessed on 25 January 2015).

3. Rugman, A. 2001. The World Trade Organization and the international political economy. In The World Trade Organization in the new global economy, Rugman, A., Boyd, G. (Eds.), MPG Books Ltd, Bodmin, UK, pp. 1-22.

4. Hoekman, B., Kostecki, M. 1995. The political economy of the world trading system. From GATT to WTO. Oxford University Press, Oxford, UK, $301 \mathrm{pp}$.

5. Winham, G., Lanoszka, A. 2001. Institutional development of the WTO. In The World Trade Organization in the new global economy, Rugman, A., Boyd, G. (Eds.), MPG Books Ltd, Bodmin, UK, pp. 23-45.

6. Canada requests WTO help over Chinese paper pulp dispute 2014. http://www.wantchinatimes.com/news-subclass-cnt.aspx?id=20141017000056\&cid=1201. [Cited 25 January 2015].

7. Forest product trade policy highlights 1998. http://www.fas.usda.gov/ffpd/woodcirculars/sep98/trdhi998.htm. [Cited 05 August 2013].

8. Factsheet: Commerce finds unfair dumping and subsidization of coated free sheet paper from the People's Republic of China 2007. http://ia.ita.doc.gov/download/factsheets/factsheet-china-cfs-adcvd-final-101707.pdf. [Cited 25 January 2015].

9. Luo, Y. 2010. Anti-Dumping in the WTO, the EU and China: the rise of legalization in the trade regime and its consequences. Kluwer Law International BV, Alphen aan den Rijn, Netherlands, 224 p. Available online: http://books.google.fi/books?id=xVqCxkuxkH4C\&pg=PP (accessed on 25 January 2015).

10. Ecuador - definitive safeguard measure on imports of medium density fiberboard. Request for consultations by Chile 2003. www.pict-pcti.org/news_archive/03/03nov/WTO_112803.doc. [Cited 25 January 2015].

11. Statement by the delegation of the Republic of Indonesia at the WTO Dispute Settlement Body Meeting 2010. http://www.mission-indonesia.org/article/193/statement-by-the-delegation-of-therepublic-of-indonesia. [Cited 25 January 2015].

12. Lysons, S. 2008. Resolving the softwood lumber dispute. Seattle University Law Review, 32(407), (407-441). Available online: http://digitalcommons.law.seattleu.edu/cgi/viewcontent.cgi?article=1937\&context=sulr $($ accessed on 25 January 2015).

13. Anderson, G. 2006. Can someone please settle this dispute? Canadian softwood lumber and the dispute settlement mechanisms of the NAFTA and the WTO. The World Economy, 29(5), (585610), 10.1111/j.1467-9701.2006.00801.x. Available online: http://onlinelibrary.wiley.com/doi/10.1111/j.1467-9701.2006.00801.x/pdf (accessed on 25 January 2015).

14. Gorte, R.W., Grimmett, J.J. 2008. Softwood lumber imports from Canada: issues and events. In Canadian imports and trade issues, Reynolds, M.B., Nelson, J.K. (Eds.), Nova Science Publishers, New York, USA, pp. 39-74. Available online: 
http://books.google.fi/books?id=MgCHKMo4DmgC\&printsec=frontcover\&dq=Canadian+imports+ and+trade+issues (accessed on 25 January 2015).

\section{WTO DSB wood trade-related dispute cases:}

Ecuador - Definitive Safeguard Measure on Imports of Medium Density Fibreboard (WTO/DS303). 24/11/2003. http://www.wto.org/english/tratop_e/dispu_e/cases_e/ds-303_e.htm Accessed: 08/04/2014

European Communities - Measures Affecting Imports of Wood of Conifers from Canada (WTO/DS137). 17/06/1998. http://www.wto.org/english/tratop_e/dispu_e/cases_e/ds137_e.htm Accessed: 08/04/2014

Korea - Anti-Dumping Duties on Imports of Certain Paper from Indonesia (WTO/DS 312). 04/06/2004. http://www.wto.org/english/tratop_e/dispu_e/cases_e/ds312_e.htm Accessed: $08 / 04 / 2014$

United States - Measures Treating Export Restraints as Subsidies (WTO/DS194). 19/05/2000. http://www.wto.org/english/tratop_e/dispu_e/cases_e/ds194_e.htm Accessed: 08/04/2014 United States - Section 129(c)(1) of the Uruguay Round Agreements Act (WTO/DS221). 17/01/2001. http://www.wto.org/english/tratop_e/dispu_e/cases_e/ds221_e.htm Accessed: $08 / 04 / 2014$

United States - Preliminary Determinations with Respect to Certain Softwood Lumber from Canada (WTO/DS236). 21/08/2001.

http://www.wto.org/english/tratop_e/dispu_e/cases_e/ds236_e.htm Accessed: 08/04/2014 United States - Provisional Anti-Dumping Measure on Imports of Certain Softwood Lumber from Canada (WTO/DS247). 06/03/2002.

http://www.wto.org/english/tratop_e/dispu_e/cases_e/ds247_e.htm Accessed: 08/04/2014 United States - Final Countervailing Duty Determination with respect to certain Softwood Lumber from Canada (WTO/DS257). 03/05/2002.

http://www.wto.org/english/tratop_e/dispu_e/cases_e/ds257_e.htm Accessed: 08/04/2014 United States - Final Dumping Determination on Softwood Lumber from Canada (WTO/264). 13/09/2002. http://www.wto.org/english/tratop_e/dispu_e/cases_e/ds264_e.htm Accessed: $08 / 04 / 2014$

United States - Investigation of the International Trade Commission in Softwood Lumber from Canada (WTO/DS277). 20/12/2002.

http://www.wto.org/english/tratop_e/dispu_e/cases_e/ds277_e.htm Accessed: 08/04/2014 United States - Preliminary Anti-Dumping and Countervailing Duty Determinations on Coated Free Sheet Paper from China (WTO/DS368). 14/09/2007. http://www.wto.org/english/tratop_e/dispu_e/cases_e/ds368_e.htm Accessed: 08/04/2014

(C) 2015 Maximova J., Karjalainen T., Pykäläinen, J. 